\title{
Organizational Culture as a Moderator Between Paternalistic Leadership Style and Organizational Commitment: A Case of Banking Sector, Pakistan
}

\author{
Zohra Kalsoom $^{1} \quad$ Mukaram Ali Khan $^{2 *} \quad$ Syed Sohaib Zubair ${ }^{3}$ \\ 1. University of Sargodha, Lahore, Pakistan \\ 2. Institute of Administrative Sciences University of the Punjab, Lahore, Pakistan \\ 3. Administrative Sciences, University of the Punjab, Pakistan
}

\begin{abstract}
This study seeks to examine the moderating role of organizational culture between Paternalistic Leadership Style and organizational commitment in the banking setting. This is an explanatory study based on 345 employees working in two private banks located in Lahore, Pakistan by using stratified sampling technique. Data were collected using the organizational commitment scale, paternalistic leadership scale and organizational culture scale. Descriptive statistics, reliability analysis, Pearson correlation were employed and hypotheses were tested using Hierarchical Multiple Regression. The results indicate that paternalistic leadership style significantly related to organizational commitment and organizational culture acted as a moderator in this relationship. Moreover, study also indicated the positive relationship between paternalistic leadership style and organizational culture and organizational commitment and organizational culture.
\end{abstract}

Keywords: Paternalistic Leadership, Organizational Culture, Organizational Commitment, Lahore, Pakistan DOI: $10.7176 / \mathrm{EJBM} / 12-1-05$

Publication date: January $31^{\text {st }} 2020$

\section{Introduction}

Organizations struggle for eternal success which depends on many external and internal factors (Alvesson \& Karreman, 2016). Out of these factors, human resource is considered to be the most valuable, strategic and crucial internal factor that leads an organization towards victory and run it competently, effectively and efficiently (Brewster, 2017). Human resource, capital, technology and quality processes are the core pillars of any organization; and can be a source of competitive advantage due to their uniqueness (Obeidat et al., 2018). Human resource is an asset that operates the processes and deal with the technology usage. That's why the attention of organizations has moved to "people" i.e. employees of an organization (Stone et al., 2015). Employees play a crucial role in organization. Their high level of involvement and commitment is a source of increase in the performance and productivity of any type of organization (Kaplan \& Kaplan, 2018). Organizational commitment is of the key parameters for any organization in order to keep satisfying the employees and expecting them to perform better for the organization in return (Yousef, 2017).

Core factors that keep employees committed and satisfied in an organization are monetary rewards, culture and leadership style as McNeese-Smith (1997) argued that employees will probably be more productive and more committed to the organization in all ups and downs if they are getting fair salary brackets, a good working condition and a better leadership style. Albion and Gagliardi (2007) argued that managing employees highly depends on the leadership style in the organization. Leadership is perceived as a contributor of numerous aspects and its power cannot be ignored (Randeree \& Chaudhry, 2012). In the time of crises in organizations, organizational decision makers emphasized the need for a true and positive guidance by the leaders and strong organizational culture development in the organization to pull back the organization from crises (Paquin, 2018). Northouse (2007) discussed that if a leader and his/her style is found trustworthy and fair, employees will follow the leader in achieving the goals and in maintaining a positive organizational culture. Though there have been number of leadership styles, but Paternalistic Leadership Style has gained immense importance from past few years. Paternalistic leadership is for the most part viewed as mostly used style of leadership in Asian societies, being profoundly established in "Chinese Confucianism" (Zhang et al., 2015). Paternalistic Leadership Style (PLS) has been defined as " $a$ style that combines strong discipline and authority with fatherly benevolence" (Chen et al., 2014, p.1).

Positive leadership style can increase commitment at organizational level by having supportive organizational culture (Celik et al., 2015). Organizational Commitment is defined as "the employee's feelings of obligation to stay with the organization: feelings resulting from the internalization of normative pressures exerted on an individual prior to entry or following entry" (Yousef, 2017, p.79) whereas Organizational Culture can be defined as "combination of artifacts (also called practices, expressive symbols, or forms), values and beliefs, and underlying assumptions that organizational members share about appropriate behavior" (Detert et al., 2000, p. $851)$. 
Financial sector, one of the paramount contributors of service industry, plays pivotal role in developing the economic life of a country (Chang, 2000). The financial service sector is prevalent in the world in terms of earnings and this sector consists of diverse range of businesses comprising banks, insurance companies and credit card companies (Sutton \& Jenkins, 2007). While talking about the financial sector of Pakistan, Bushra et al., (2011) explored that today's economy is heavily dependent on banking sector in terms of day to day transactions and banks play vibrant and advantageous role in the progress of a developing country like ours. Samuel (2011) conducted a research in banking sector and established the relations of leadership, job satisfaction (JS) and organizational commitment (OC). Study concluded that leadership style is one of the most important aspects in increasing the employee commitment level and in providing a good and a professional environment. He further mentioned about the significant and positive relations of leadership style and service quality, leadership style and OC and leadership style and JS. Environment of a bank influences the effectiveness of leadership and its influence on behavioral and performance outcomes of employees (Malhotra \& Mukherjee, 2004). Therefore, influence of culture on the relationship of leadership and outcomes is of paramount importance and requires in-depth investigation. An attempt had been made to find empirical evidence in Pakistan, but it was observed that this area was largely ignored in this part of the world, which validated the premise of this investigation. Therefore, the present study is framed in Pakistani context and has been carried out in the banking sector of Pakistan. It would be interesting to see how culture act as a moderating variable and influence the relation of paternalistic leadership style and organizational commitment within banking sector.

\subsection{Objectives of the study}

The study seeks to explore that how culture act as a moderating variable. Main objectives of the study include the following:

i. To explore the existence of a relation between Paternalistic Leadership Style (PLS) and Organizational Commitment (OC)

ii. To test the impact of a relation between Paternalistic Leadership Style (PLS) and Organizational Culture

iii. To explore the existence of a relation between Organizational Culture and Organizational Commitment (OC)

iv. To investigate the moderating role of organizational culture between PLS and OC

\subsection{Significance}

The key feature of the research is that it will help the organizations to develop strong organizational culture and adopt such leadership style which will be advantageous and which will provide them higher productivity and profitability. Leaders in any organization are the ones that can motivate and can demotivate the employees therefore it is essential for the organizations to choose the best and most effective leadership style. Practically it will help the managers of banking sector to understand which leadership style makes employees more committed and loyal towards the organization. It will also help the managers to recognize that when employees are committed, they participate in such behaviors that increase the overall productivity of organization.

The research work will also help the policy makers to revamp their strategy as to improve its human resources and organization related issues, since organizations are continuously fighting over to develop the best organizational culture and to find the suitable ways of encouraging employees to improve their work productivity. This study will generate valuable facts on the current culture of the private banks of Lahore, Pakistan. This study will contribute in the extension of management and HRM literature. On the basis of this study, managers will be able to discover best methods to develop better culture which leads employees towards OC. Therefore, organizations should critically analyze which type of culture and leadership style will be advantageous for them and subsequently organizations should appropriately proclaim it to every individual respectively with the intention of making and keeping a committed workforce.

\section{Literature Review}

Leadership is one of the greatest study matters in social sciences. It is a common action and is apparent in humans and animals (Bass, 2008). According to Van Vugt (2006), sociologists agree upon that no human societies exist in the absence of leadership. Leadership exists in all cultures and is present since the people have cooperated with each other (Rukmani et al., 2010). Leadership is very significant for all cultures but regardless of its significance, little consensus is present about its origins, definitions and importance (Celik et al., 2015; Dickson et al., 2003). It is notable that the word leadership becomes visible in the British Parliament for the first time around 200 years ago (Dorfman, 1996). According to Northouse (2007), leadership is a process and the ability of an individual to inspire a group of people towards the accomplishment of mutual goals. Aksu (2009) stated that for every kind of problem in the organizations, there is a suitable leadership theory.

\subsection{Paternalistic Leadership}

Paternalism is originated from the Latin language and word 'pater' meaning 'father' (Oner, 2012). There has been 
extensive amount of research on Paternalistic leadership in the last few years (Chan et al., 2012). In the last two decades paternalistic leadership has got great attention around the world (Aycan, 2006; Pearce, 2005; Pellegrini \& Scandura, 2008). Paternalism can be linked to the early works of Max Weber. Weber hypothesized that paternalism is one form of legitimate authority (Pellegrini \& Scandura, 2008). Scholars of leadership studies have identified that Asian countries give more favor to this form of legitimate authority (DenHartog, 2004). In Asia, Paternalistic leadership is an influenced leadership (Chan et al., 2012). Farh and Cheng (2000) argue that in Asia paternalistic leadership is based on the ideology of Confucianism. Wang and Cheng (2010) argue that paternalistic leadership was proposed as a prime Chinese Leadership theory. The concept of this leadership theory was developed to cover the behavior of Chinese business leaders in organizations (Farh \& Cheng, 2000). Uhl-Bien and Maslyn (2005) state that paternalistic leadership is considered negative in the Western world whereas Pellegrini and Scandura (2008) argue that in non-Western world like India, Pakistan, China, Japan and Turkey, it is perceived as positive style. This style has received a great attention in the non-Western culture (Farh et al., 2008).

\subsection{Organizational Culture}

Organizational culture is a widely used term. The concept of culture is extracted from the metaphor as something cultivated (Watson, 2006). According to Hofstede (2001) culture exists at different levels in the organization. It is the responsibility of managers to develop a strong organizational culture in the organization (Watson, 2006). Organizational culture has been described by Poskiene (2006) as the complex set of philosophies, commitment, values, assumptions, beliefs and norms that are shared among the members and that joins an organization together and become a source of advantage and innovation for the organization.

Culture can be divided into different categories. Daft (2005) classified the organizational culture as Adaptability, Clan, Achievement and Bureaucratic. Culture can also be divided in Clan, Adhocracy, Market and Hierarchy cultures (Cameron \& Freeman, 1991; Quinn \& Rohrbaugh, 1983). Goffee and Jones (1998) classified culture into Communal, Fragmented, Networked and Mercenary types. Wallach (1983) categorized culture into three types as Bureaucratic, Innovative and supportive culture. Wallach's (1983) categorization of culture is utilized for this study, as it is widely used and accepted categorization. Wallach (1983) stated that these three categories are the lifeblood of an organization.

A bureaucratic culture is managed by rules and regulations. In such culture employee is not given empowerment and employee fulfills his tasks as specified by his managers and an employee is not given any freedom in such culture. This type of culture is a hierarchical culture (Kaungo et al., 2001). In this type of culture, managers can effectively control, administer, coordinate and maintain efficiency (Cameron \& Quinn, 1999). Williams and Attaway (1996) stated that bureaucratic culture is slow to change. In such culture, participant's jobs and duties are contractual in nature and the roles of participants are setoff in advance. The congruity of goals is low in such culture and for the attainment of goals; each group uses the other group for its own purpose.

The supportive culture emphasizes on team work and collaboration. Such culture is people-oriented and employees collaborate with each other in a trusting working environment (Kaungo et al., 2001). A supportive culture consists of teamwork and trusting working environment. People are usually friendly and cooperative. In such culture employees encourage each other's contributions and accomplishments and support each other (Marks et al., 2001). In a supportive culture, empowerment and cooperation level is very high. In such culture, managerial control is also present but this control is only based on inter-relationships and socialization which leads to a mutual commitment of both the manager and the subordinate. The congruity of goals is high in supportive culture and participants of supportive culture share healthy goal congruence (Williams \& Attaway, 1996).

\subsection{Organizational Commitment}

Organizational commitment (OC) is a broader concept that can be overlapped with the other concepts such as job involvement and career satisfaction (Reichers, 1985). For more than thirty years organizational commitment is considered as a significant topic of organizational studies (Fisher et al., 2010). Extensive amount of research is present about organizational commitment and different scholars and researchers have identified various antecedents and outcomes of organizational commitment (Elele \& Fields, 2010). OC is an approach that defines the connection between the employee and the organization and to demonstrate this connection, employee follow a set of behaviors called organizational commitment (Stites \& Michael, 2011).

Meyer and Allen (1990) identified that there are three elements of organizational commitment: Affective commitment (AC), Continuance commitment (CC) and Normative commitment (NC). Organizational commitment remain to be a significant area for research in HRM and management and this study will cover all the three components of commitment i.e., $\mathrm{AC}, \mathrm{NC}$ and $\mathrm{CC}$ and the contemporary investigation finds out its relationships with Paternalistic leadership style.

\section{Conceptual Framework and Hypotheses Development}

Leadership styles are the basis of organizational commitment (Williams \& Hazer, 1986). Committed employees 
are important factors in achieving the organizational goals and leadership behavior is noteworthy in maintaining the workers commitment (Firth et al., 2004). Leadership behavior is directly related with employee's outcomes such as employee's commitment (Erkutlu, 2008). Employee's commitment is greatly influenced by the leader's behavior such as creativity and supportiveness. In order to keep an employee committed, there must be effective communication and trustworthiness between employee and leader (Avolio et al., 2004). Bass (2008) found that followers show higher level of organizational commitment when a leader trust the followers, include the followers in decision-making, motivate the followers to apply new techniques and methods to solve the problems and identify the follower's needs. Walumbwa and Lawler (2003) found that leaders who recognize the needs of the followers and motivate them to work with their full potential, their employees show higher level of organizational commitment. Leaders who motivate the followers, their follower's dignity, self-actualization and morale are increased by the action of their leaders which ultimately enhance the employee's commitment for their organization (Srithongrung, 2011).

Erben and Guneser (2008) established a significant positive association of paternalistic leadership style and OC. Their study resulted that all three elements of paternalistic leadership (Authoritarianism, Benevolence, Moral leadership) is positively linked with the three types of OC (AC, NC, CC). Moreover, Rehman and Afsar (2012) conducted a study in SME's of Pakistan and they found that paternalistic leadership has positive impact on increasing the commitment of employees. It can be hypothesized by considering previous findings that:

$H_{1}$ : There is a positive relationship between paternalistic leadership style and organizational commitment.

Leadership style is an important aspect to accomplish organizational goals. Numerous factors contribute to organization's success, such as leadership style and organizational environment that plays a fundamental role in the success of an organization (Lecturer, 2018). Various studies show that paternalistic leadership is significantly related with organizational culture (Ciralkar et al., 2016). According to Harwiki (2016), employees can adjust to the organization's environment and can perform better if they get a fair guide to carry out their tasks and duties. Gupta and Sharma (2016) proposed that leaders with clear vision and benevolent style enhance employee's ability to perform their duties and such leaders help in creating and maintaining a positive and fair culture in organizations.

A study conducted by Sinaga et al., (2018) concluded that there is a direct positive relationship between leadership style and organizational culture. In their study, they have found out that leaders, who take care of employees' needs, inspire their subordinates, and help them in achieving their goals as well as organizational goals effectively, become a role model and such leaders create positive environment in workplace and help in increasing organizational productivity. Bedi (2019) conducted a meta-analysis review of paternalistic leadership and found the association between paternalistic leadership and followers results with their tasks and duties. The findings suggested that both benevolence leadership and moral leadership significantly and positively affect the followers' outcomes while authoritarian leadership is negatively associated with the followers result. And organizational environment plays a consequential role in the association between paternalistic leadership style and followers work outcomes.

Liu (2014) did a research on Chinese SMEs (Small and Medium Enterprises). The purpose of this investigation was to explore the linkage between organizational culture and paternalistic leadership style. His study resulted that all four types of culture (Group culture, Developmental Culture, Hierarchical culture and Rational culture) have positive association with all three components of paternalistic leadership style i.e., Benevolent leadership, Moral leadership and Authoritarian leadership.

Yuzbasioglu and Dogan (2018) conducted a study with a sample of 243 employees of hotel industries functioning in Antalya, Turkey. They found out that there is a positive direct relationship between paternalistic leadership style and organizational culture. Paternalistic leaders can increase the commitment of employees and together paternalistic leaders and employees can make a positive work environment. Following hypothesis has been developed on the basis of aforementioned findings;

$\mathrm{H}_{2}$ : There is a positive relationship between paternalistic leadership style and organizational culture

Significant work has been done on organizational commitment and organizational culture in different settings (Mohammadi \& Zarei, 2015; Ismail \& Razak, 2016; Anitha \& Begum, 2016; Inanlou \& Ahn, 2017; and AlShurufat \& Halim, 2018). Hadian (2017) pointed out that many researches show the significant relationship between organizational commitment and organizational culture and they both majorly contribute in organizational performance. Edward (2016) argued that organizational culture is the most vital factor of organizational achievement and organizational commitment. Anitha and Begum (2016) conducted a research on service sector and found a positive and significant association between organizational commitment and organizational culture.

Al-Shurufat and Halim (2018) reviewed a number of studies on organizational commitment and organizational culture. Their paper pointed out that there is a strong significant relationship between organizational commitment and organizational culture, however in some studies they found out the weak association between these variables as well. Wiseman et al., (2017) conducted a study on a selected higher education institution in South Africa. Results of their research revealed a strong and positive relationship between organizational commitment and organizational culture. Azizollah et al., (2016) carried out a study in Zahden University of 
Medical Sciences and studied the relationship between organizational commitment and organizational culture. Findings of their study pointed out a strong and significant relationship between organizational culture and all three dimensions of organizational commitment (affective commitment, normative commitment and continuance commitment). Mitic et al., (2016) conducted a study on 129 companies in Serbia and found the effect of certain components of organizational culture (future orientation, power distance, human orientation and performance orientation). Results of their study showed that dimensions of organizational culture are significantly correlated with organizational commitment.

Carvalho et al., (2018) investigated the relationship between organizational culture (clan culture, hierarchical culture, adhocracy culture and market culture) and organizational commitment in the banking sector of Brazil. The study results suggested that Clan culture has a significant effect on all types of organizational commitment; Hierarchical culture has no significant correlation with affective commitment but has a significant relationship with continuance commitment and normative commitment. Similarly the results indicated that Adhocracy culture is significantly linked with affective commitment and normative commitment, while on the other hand Market culture has a significant and positive correlation with the continuance commitment. Wambui and Gichanga (2018) concluded that organizational commitment and organizational culture are significantly linked with each other and organizational culture has a crucial role in determining an employee's commitment. Mohammadi and Zarei (2015) examined the relationship between organizational commitment and organizational culture in Fajr Jam Gas Refinery with a sample of 280 subjects. The result of their study showed a strong and significant relationship between organizational commitment and organizational culture. Based on the previous findings, it can be hypothesized;

$H_{3}$ : There is a positive relationship between organizational commitment and organizational culture

Organizational culture has important role in producing commitment and increasing the performance of employee (Lok \& Crawford, 2001). Studies show that innovative and supportive culture is positively related with commitment and job satisfaction (Rashid, et al., 2003; Silverthorne, 2004). Fisher and Mansell (2009) stated that meta-analytic analysis research on commitment shows that affective commitment, normative commitment and continuous commitment along with leadership have same shares across cultures as other variables have. Organizational culture and leadership are two closely linked terms (Schein, 2004). Gelfand et al., (2007) pointed out that in the leadership and commitment research there is an indication for both generalizability and culture uniqueness. Randeree and Chaudhry (2012) argued that leadership styles may differ across cultures. According to Yukl (2002) certain leadership styles may influence innovation through cooperation with organizational culture. Li (2004) pointed out that different leadership behaviors have influenced on organizational commitment and this influence is dependent on organizational culture. In her study, it was found that all three kinds of organizational culture (Bureaucratic, Innovative and Supportive) acted as a moderating variable in the association of leadership behavior with OC. Moreover this moderation effect was found negative in her study.

Yiing and Ahmad (2009) posited that organizational culture has no effect on the association of leadership behavior and OC. This hypothesis was partially rejected in their study as they found organizational culture a significant moderating variable in the association of leadership behavior and OC. Bureaucratic, Innovative and Supportive cultures were found significant moderating variables in the relationship of participative and supportive leadership behaviors with $\mathrm{OC}$ while on the other hand, bureaucratic culture did not significantly moderated the relationship of directive leadership behavior with organizational commitment but the innovative and supportive cultures were significant moderating variables in the association of directive leadership behavior with OC. Considering previous findings it can be hypothesized that:

$\mathrm{H}_{4}$ : Organizational culture (Innovative, supportive and Bureaucratic) can moderates the relationship between paternalistic leadership style and organizational commitment 


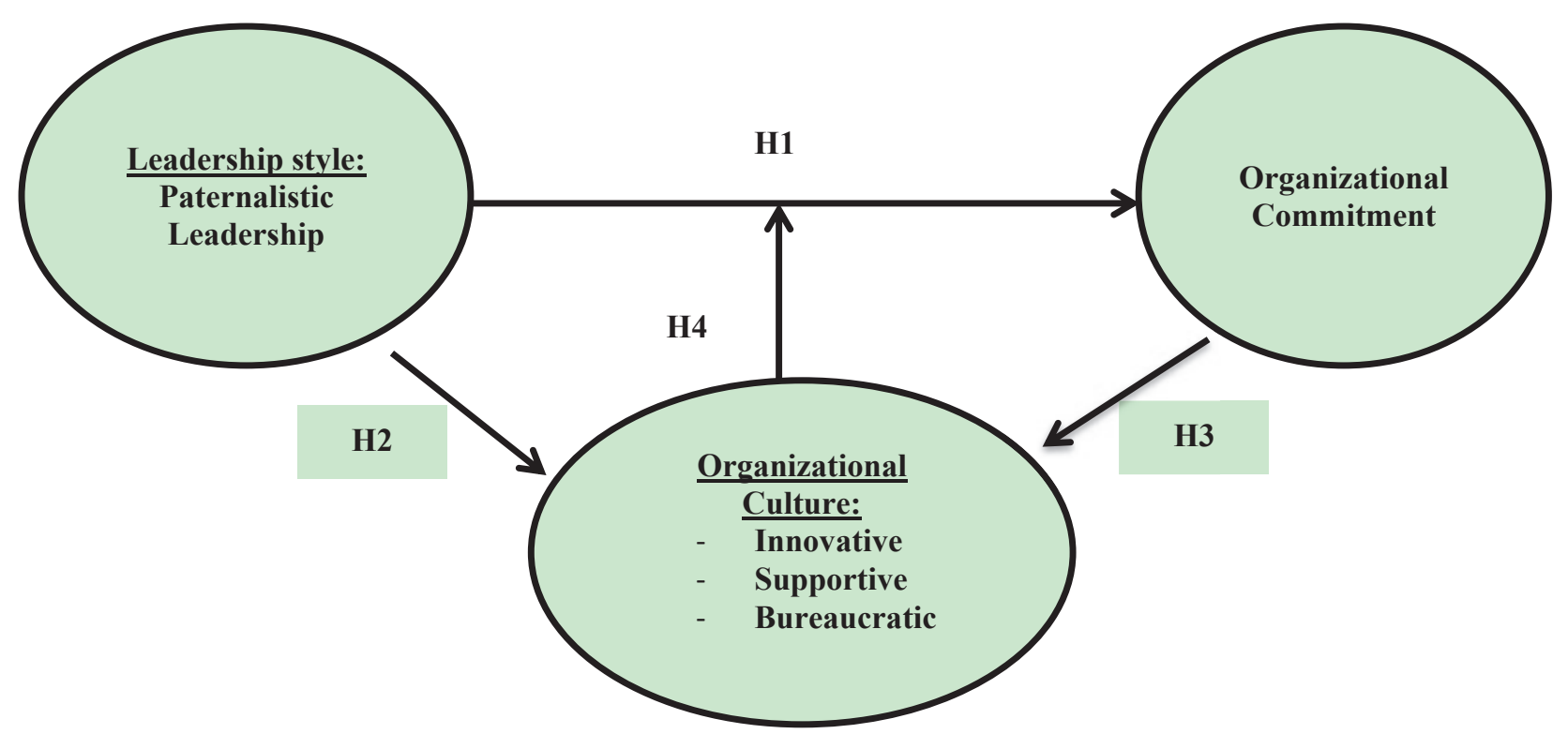

Figure 2: Research Model

\section{Methodology}

This study is causal in nature with quantitative strategy been used. Cross section research design has been used as researchers have collected data at one point of time. The population is the private banks in Lahore, Pakistan. The target populations of current study are the employees from managerial level and non-managerial level of private banks Lahore, Pakistan. HBL and Silk Bank have been selected for collection of data. The reason for selecting these banks is that these two banks are private, where HBL is the largest private bank of Pakistan, Silk Bank is also expanding its branch network and has a good position in banking sector of Pakistan. Also these two banks cover a great proportion of the banked population of Pakistan. So the selection of these two banks was made to fulfill the objectives of this study. The sample size for employees was calculated based on Yamane's formula (Yamane, 1967). Thus a random sample of size 345 is selected for this study using random sampling strategy with the help of sampling frame list.

A structural questionnaire is used in order to collect data. The questionnaire is based on 36 items, out of which 13 questions are adapted to measure PLS, 15 items measures the organizational culture and 8 items measure the organizational commitment using five point Likert scale.

The instruments of this study were adopted from different researchers and as follows;

Table 1: Questionnaire Classification

\begin{tabular}{lcr}
\hline \multicolumn{1}{c}{ Variables } & No. of Items & Source \\
\hline Paternalistic Leadership Scale & 13 & Pellegrini and Scandu \\
Organizational Culture & 15 & Raed Ismail Ababaneh \\
Organizational Commitment & 08 & Porter et al., (19 \\
\hline As far as reliability is concerned, this study has used Chronback's Alpha to check the reliability. \\
Gliem (2003) provided the following rule of thumb for the Cronbach's alpha. i.e.: Reliability $>0$ \\
Reliability $>0.8$ good, Reliability $>0.7$ acceptable, Reliability $>0.6$ questionable, Reliability $>0.5$ \\
Reliability $<0.5$ unacceptable. & & \\
Table 2: Reliability Statistics & No. of items & Cronbach Alpha \\
Variables under study & 5 & 0.948 \\
Bureaucratic Culture & 5 & 0.951 \\
Innovative Culture & 5 & 0.951 \\
Supportive Culture & 13 & 0.984 \\
Paternalistic Leadership & 8 & 0.929 \\
Organizational Commitment & & \\
\hline
\end{tabular}

\section{Data Analysis}

Data analysis has been done through descriptive statistics and inferential statistics. Table 3 discusses the demographic characteristics. 
Table 3: Demographic Characteristics

\begin{tabular}{cccc}
\hline Characteristics & Category & Frequency & Percent (\%) \\
\hline Name of the Bank & HBL & 305 & 88.4 \\
Gender of the & Silk Bank & 40 & 11.6 \\
Respondent & Male & 313 & 90.7 \\
& Female & 32 & 9.3 \\
Level of Job & Lower level Job & 103 & 29.9 \\
& Middle Level Job & 173 & 50.1 \\
& Top Level Job & 69 & 20.0 \\
Age of the & 20 or less & 14 & 4.1 \\
Respondent & 21 to 30 & 98 & 28.4 \\
& 31 to 40 & 166 & 48.1 \\
& 41 or above & 67 & 19.4 \\
Experience with & 1 or less & 91 & 26.4 \\
current & 6 to 5 & 165 & 47.8 \\
organization & 10 or above & 70 & 20.3 \\
\hline
\end{tabular}

305 employees belong to HBL and have a proportion of $88.4 \%$ whereas 40 employees have been selected from Silk Bank and have a proportion of $11.6 \%$. On the basis of level of job, 103 employees with $29.9 \%$ belong to the lower level, 173 employees belong to the middle level with a proportion of $50.1 \%$ and 69 employees were belong to the top level and had a proportion of $20 \%$. Rest details are self-explanatory and are presented in the above table.

Table 4: Descriptive Statistics

\begin{tabular}{ccc}
\hline Variables under study & Mean & Std. Deviation \\
\hline Paternalistic Leadership & 3.3833 & 1.17905 \\
Organizational Commitment & 3.6967 & .91072 \\
Bureaucratic Culture & 3.2968 & 1.17929 \\
Innovative Culture & 3.3942 & 1.22150 \\
Supportive Culture & 3.5241 & 1.24402 \\
\hline
\end{tabular}

Table 4 discusses the descriptive statistics of the study by taking mean and standard deviation. The descriptive analysis showed that the association between organizational commitment and variables Paternalistic Leadership, Bureaucratic Culture, Innovative Culture and Supportive Culture lied at 3. It demonstrated that they have propensity in the direction of mean. Moreover, employees showed greatest commitment towards their organization. The employees were satisfied and happy for working in this organization and had no contrition on their decision for working in their organizations.

$\boldsymbol{H}_{1}$ : There is a positive relationship between paternalistic leadership style and organizational commitment.

$\boldsymbol{H}_{2(1)}$ : There is a positive relationship between paternalistic leadership style and bureaucratic culture.

$\boldsymbol{H}_{2(2):}$ There is a positive relationship between paternalistic leadership style and innovative culture.

$\boldsymbol{H}_{2(3):}$ : There is a positive relationship between paternalistic leadership style and supportive culture.

$\boldsymbol{H}_{3(1)}$ : There is a positive relationship between organizational commitment and bureaucratic culture.

$\boldsymbol{H}_{3(2)}$ : There is a positive relationship between organizational commitment and innovative culture.

$\boldsymbol{H}_{3(3)}$ : There is a positive relationship between organizational commitment and supportive culture. 
Table 5: Correlation Matrix

\begin{tabular}{|c|c|c|c|c|c|c|}
\hline & & $\begin{array}{c}\text { Paternalistic } \\
\text { Leadership }\end{array}$ & $\begin{array}{l}\text { Organizational } \\
\text { Commitment }\end{array}$ & $\begin{array}{c}\text { Bureaucratic } \\
\text { Culture }\end{array}$ & $\begin{array}{l}\text { Innovative } \\
\text { Culture }\end{array}$ & $\begin{array}{l}\text { Supportive } \\
\text { Culture }\end{array}$ \\
\hline \multirow[t]{3}{*}{$\begin{array}{l}\text { Paternalistic } \\
\text { Leadership }\end{array}$} & $\begin{array}{l}\text { Pearson } \\
\text { Correlation }\end{array}$ & 1 & $.805^{* *}$ & $.246^{* *}$ & $.778^{* *}$ & $.755^{* *}$ \\
\hline & Sig. (1-tailed) & & .005 & .008 & .000 & .000 \\
\hline & $\mathrm{N}$ & 345 & 345 & 345 & 345 & 345 \\
\hline \multirow[t]{3}{*}{$\begin{array}{l}\text { Organizational } \\
\text { Commitment }\end{array}$} & $\begin{array}{l}\text { Pearson } \\
\text { Correlation }\end{array}$ & $.805^{* *}$ & 1 & $.208^{* *}$ & $.702^{* *}$ & $.891^{* *}$ \\
\hline & Sig. (1-tailed) & .005 & & .000 & .000 & .000 \\
\hline & $\mathrm{N}$ & 345 & 345 & 345 & 345 & 345 \\
\hline \multirow[t]{3}{*}{ Bureaucratic Culture } & $\begin{array}{l}\text { Pearson } \\
\text { Correlation }\end{array}$ & $.246^{* *}$ & $.208^{* *}$ & 1 & $.919^{* *}$ & $.935^{* *}$ \\
\hline & Sig. (1-tailed) & .008 & .000 & & .000 & .000 \\
\hline & $\mathrm{N}$ & 345 & 345 & 345 & 345 & 345 \\
\hline \multirow[t]{3}{*}{ Innovative Culture } & $\begin{array}{l}\text { Pearson } \\
\text { Correlation }\end{array}$ & $.778^{* *}$ & $.702^{* *}$ & $.919^{* *}$ & 1 & $.941^{* *}$ \\
\hline & Sig. (1-tailed) & .000 & .000 & .000 & & .000 \\
\hline & $\mathrm{N}$ & 345 & 345 & 345 & 345 & 345 \\
\hline \multirow[t]{3}{*}{ Supportive Culture } & $\begin{array}{l}\text { Pearson } \\
\text { Correlation }\end{array}$ & $.755^{* *}$ & $.891^{* *}$ & $.935^{* *}$ & $.941^{* *}$ & 1 \\
\hline & Sig. (1-tailed) & .000 & .000 & .000 & .000 & \\
\hline & $\mathrm{N}$ & 345 & 345 & 345 & 345 & 345 \\
\hline
\end{tabular}

**. Correlation is significant at the 0.01 level (1-tailed).

The results in the above Table 5 demonstrated that Pearson Correlation is .805 between PLS and OC. The pvalue 0.005 is less than level of significance 0.01 . Hence, the result could be stated that there is a strong positive correlation between paternalistic leadership style and OC. Significant scores of paternalistic leadership style produce greater $\mathrm{OC}$ in workers. Therefore, $\mathrm{H}_{1}$ is accepted and concludes that there is a positive relationship between paternalistic leadership style and organizational commitment.

Moreover, as far as relationship between PLS and organizational culture (bureaucratic, innovative and supportive) is concerned, table 5 demonstrated that Pearson Correlation is $0.246,0.778$ and 0.755 between PLS and Bureaucratic culture, innovative culture and supportive culture respectively at p-value $0.008,0.000$ and 0.000 respectively i.e. less than level of significance 0.01 . Hence, the result could be stated that there is a strong positive correlation between paternalistic leadership style and organizational culture (innovative and supportive) whereas weak positive relation between PLS and bureaucratic culture. Therefore, $\mathrm{H}_{2(1)}, \mathrm{H}_{2(2)}, \mathrm{H}_{2(3)}$ are accepted and concludes that there is a positive relationship between paternalistic leadership style and all dimensions of organizational culture.

Furthermore, table 5 also depicted the relationship between OC and dimensions of organizational culture. Pearson Correlation found to be $0.208,0.702$ and 0.891 between OC and Bureaucratic culture, innovative culture and supportive culture respectively at p-value 0.000 i.e. less than level of significance 0.01 . Hence, the result could be stated that there is a strong positive correlation between OC and organizational culture (innovative and supportive) whereas weak positive relationship between OC and bureaucratic culture. Therefore, $\mathrm{H}_{3(1)}, \mathrm{H}_{3(2)}, \mathrm{H}_{3(3)}$ are accepted.

$\boldsymbol{H}_{4}$ : Organizational Culture can moderate the relationship of paternalistic leadership style and organizational commitment.

$\boldsymbol{H}_{4(1)}$ : Bureaucratic Culture can moderate the relationship of paternalistic leadership style and organizational commitment. 
Table 6: Results of Hierarchical Regression Analysis of Organizational Commitment on Paternalistic Leadership in Bureaucratic Culture

\begin{tabular}{|c|c|c|c|c|c|c|c|c|}
\hline Independent & \multicolumn{4}{|c|}{ Model Summary } & \multicolumn{4}{|c|}{ Coefficients $^{\mathrm{d}}$} \\
\hline Paternal & $\begin{array}{c}R^{2} \text { excl. } \\
\text { interaction }^{\mathrm{a}}\end{array}$ & $\begin{array}{c}R^{2} \text { incl. } \\
\text { interaction }^{\mathrm{b}}\end{array}$ & $\Delta R^{2}$ & $\begin{array}{l}\text { Sig. } F \\
\text { change }\end{array}$ & $B$ & Beta & $\overline{\mathrm{T}}$ & Sig. \\
\hline Leadership & 0.876 & 0.899 & 0.023 & 0.00 & -1.244 & -1.629 & -8.85 & 0.089 \\
\hline
\end{tabular}

Notes: ${ }^{a} R^{2}$ including paternalistic leadership and bureaucratic culture, but excluding the interaction paternalistic leadership * bureaucratic culture; ${ }^{b} R^{2}$ including interaction term paternalistic leadership * bureaucratic culture; ${ }^{\mathrm{d} C o e f f i c i e n t s}$ of bureaucratic culture in the model: (constant), paternalistic leadership, bureaucratic culture, paternalistic leadership * bureaucratic culture

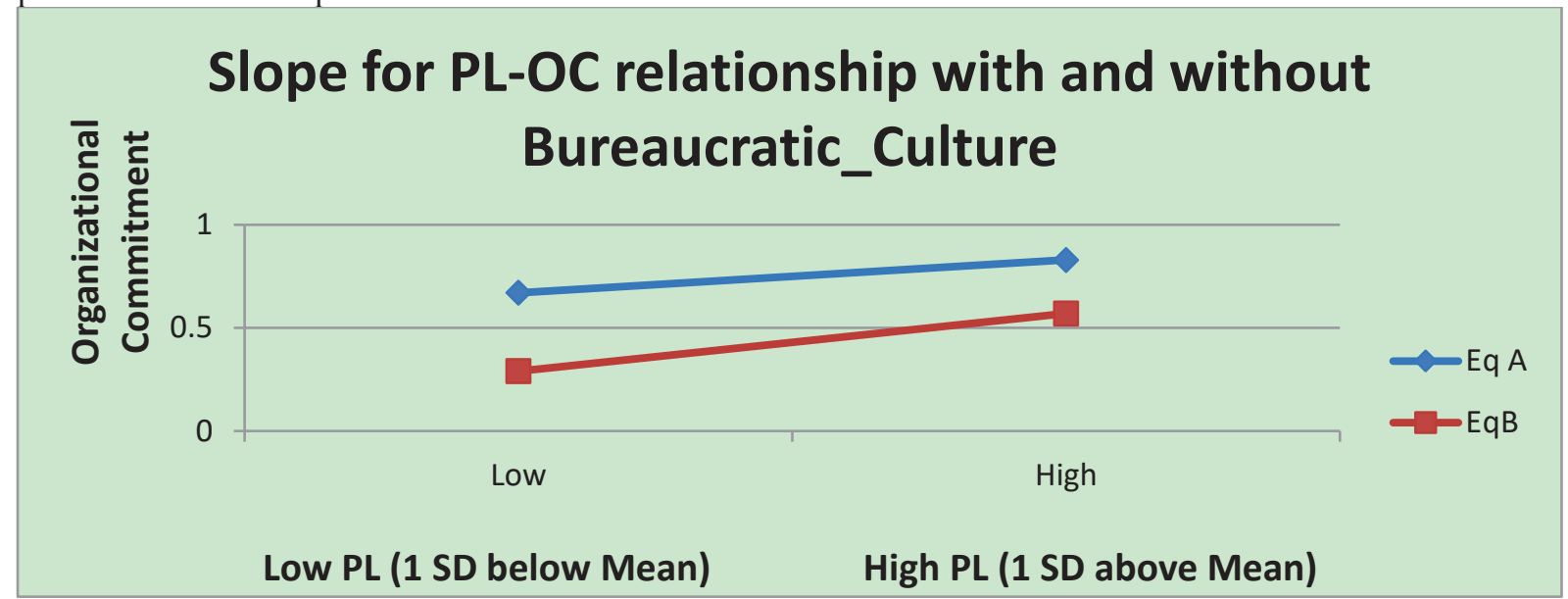

Figure 3: Interactive Effects of Paternalistic Leadership and Bureaucratic Culture on Organizational Commitment

$\boldsymbol{H}_{4(2):}$ Innovative Culture can moderate the relationship of paternalistic leadership style and organizational commitment.

Table 7: Results of Hierarchical Regression Analysis of Organizational Commitment on Paternalistic Leadership in Innovative Culture

\begin{tabular}{|c|c|c|c|c|c|c|c|c|}
\hline $\begin{array}{c}\text { Tndependent } \\
\text { Variables }\end{array}$ & \multicolumn{4}{|c|}{ Model Summary } & \multicolumn{4}{|c|}{ Coefficients $^{\top}$} \\
\hline Paternalistic & $\begin{array}{c}R^{2} \text { excl. } \\
\text { interaction }^{\mathrm{a}}\end{array}$ & $\begin{array}{c}R^{2} \text { incl. } \\
\text { interaction }\end{array}$ & $\Delta R^{2}$ & $\begin{array}{l}\text { Sig. } F \\
\text { change }\end{array}$ & $B$ & Beta & $\mathrm{t}$ & Sig. \\
\hline Leadership & 0.824 & 0.831 & 0.007 & 0.000 & -0.850 & -1.139 & -3.621 & 0.000 \\
\hline
\end{tabular}

Notes: ${ }^{a} R^{2}$ including paternalistic leadership and innovative culture, but excluding the interaction paternalistic leadership * innovative culture; ${ }^{b} R^{2}$ including interaction term paternalistic leadership * innovative culture; ${ }^{\mathrm{d} C o e f f i c i e n t s}$ of innovative culture in the model: (constant), paternalistic leadership, innovative culture, paternalistic leadership * innovative culture

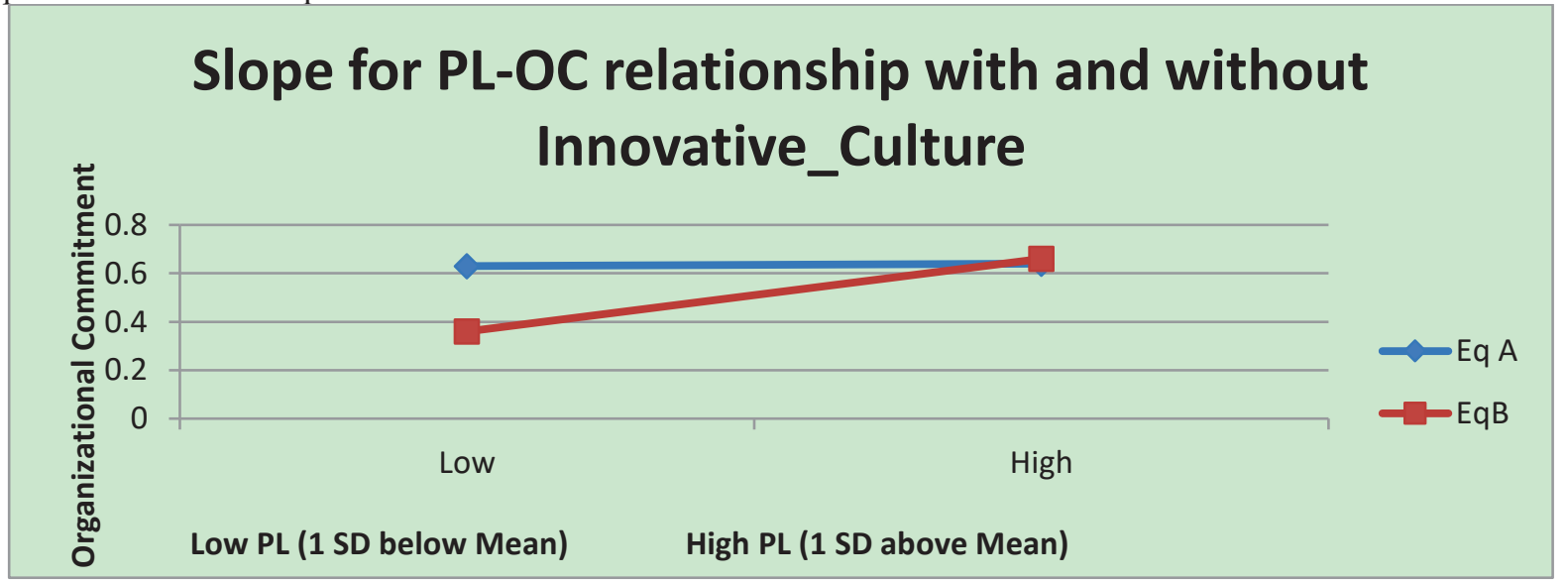

Figure 4: Interactive Effects of Paternalistic Leadership and Innovative Culture on Organizational Commitment $\boldsymbol{H}_{4(3) \text { : }}$ Supportive Culture can moderate the relationship of paternalistic leadership style and organizational commitment. 
Table 8: Results of Hierarchical Regression Analysis of Organizational Commitment on Paternalistic Leadership in Supportive Culture

\begin{tabular}{|c|c|c|c|c|c|c|c|c|}
\hline \multirow{2}{*}{$\begin{array}{c}\text { Independent } \\
\text { Variables } \\
\text { Paternalistic }\end{array}$} & \multicolumn{4}{|c|}{ Model Summary } & \multicolumn{4}{|c|}{ Coefficients $^{d}$} \\
\hline & $\begin{array}{c}R^{2} \text { excl. } \\
\text { interaction }\end{array}$ & $\begin{array}{c}R^{2} \text { incl. } \\
\text { interaction }^{\mathrm{b}}\end{array}$ & $\Delta R^{2}$ & $\begin{array}{l}\text { Sig. } F \\
\text { change }\end{array}$ & $B$ & Beta & $\mathrm{t}$ & Sig. \\
\hline Leadership & 0.845 & 0.864 & 0.019 & 0.000 & -1.520 & -2.060 & -6.844 & 0.000 \\
\hline
\end{tabular}

Notes: ${ }^{a} R^{2}$ including paternalistic leadership and supportive culture, but excluding the interaction paternalistic leadership * supportive culture; ${ }^{b} R^{2}$ including interaction term paternalistic leadership * supportive culture; ${ }^{\mathrm{d} C o e f f i c i e n t s}$ of supportive culture in the model: (constant), paternalistic leadership, supportive culture, paternalistic leadership * supportive culture

\section{Slope for PL-OC relationship with and without Supportive_Culture}

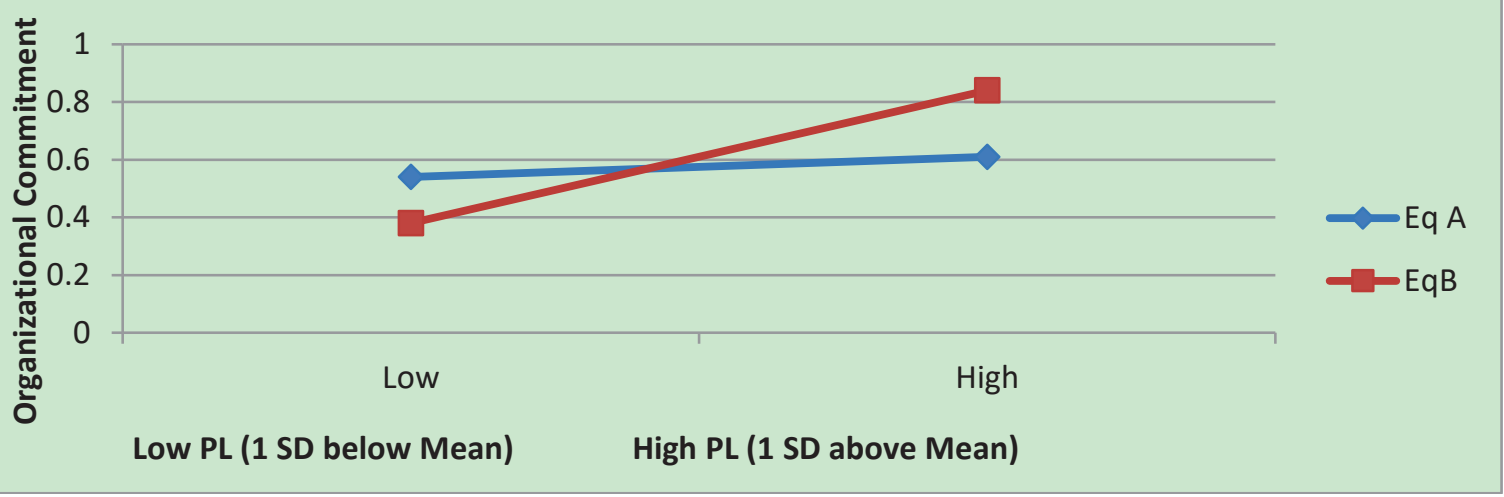

Figure 5: Interactive Effects of Paternalistic Leadership and Supportive Culture on Organizational Commitment $\mathrm{H}_{4}$ stated that Organizational Culture (Bureaucratic, Innovative and Supportive) has moderating effects on the relation of paternalistic leadership style and organizational commitment. Table 6-8 showed that positive association between paternalistic leadership and OC was weakened after adding the moderating variables (Bureaucratic, Innovative and Supportive). The interaction impacts for paternalistic leadership and bureaucratic culture $\left(\Delta \mathrm{R}^{2}=0.023, \beta=-1.244, p>0.05\right)$, innovative culture $\left(\Delta \mathrm{R}^{2}=0.007, \beta=-0.850, p<0.05\right)$, and supportive culture $\left(\Delta \mathrm{R}^{2}=0.019, \beta=-2.060, p<0.05\right)$ were significant for organizational commitment, supporting $H_{4(2)}$ and $H_{4(3)}$ and rejecting $H_{4(1)}$, Therefore, the null hypothesis pertaining $H_{4}$ is partially rejected. Organizational Culture (Innovative and Supportive) has significant negative moderating effect on the relationship between paternalistic leadership style and organizational commitment whereas bureaucratic culture couldn't moderate the relationship. Figure 2-4 graphically presents the interactional paternalistic leadership - organizational commitment association as moderated by bureaucratic, innovative and supportive culture, for which high and low levels are represented as one SD above and below the mean, correspondingly.

\section{Conclusion}

This study explores the relationships among paternalistic leadership style, organizational commitment, and organizational culture based on two private banks in Lahore, Pakistan. After complete analysis, it is found that all hypotheses of the study are supported and just $\mathrm{H}_{4(1)}$ is partially rejected as bureaucratic culture did not significantly moderated the relationship of paternalistic leadership style and organizational commitment. This could be due to the bureaucratic environment of banks where employees are not given freedom and empowerment and employees fulfill their tasks as specified by the manager. Moreover, the commitment of employees is effective by the leadership style and culture of the organization. The results from current investigation can aid in developing and understanding the effect of leadership style and organizational culture towards organizational commitment in Pakistani Private banking sector. This study is a significant contribution and helps the policy makers who plan to improve their prevailing working structure. In a nutshell, leader's style and culture of the organization influences the commitment of workers which ultimately leads to organizational growth and productivity. Therefore, with a true and positive leadership style and comfortable working environment in the organization, employees are most likely to perform their tasks effectively and develop a greatest commitment towards their organizations in the long run. 


\section{LIMITATIONS AND FUTURE DIRECTIONS}

This research is accompanied with certain limitations. Following are the limitations of this study:

i. This study has been limited to private banking sector in Lahore, Pakistan. Further research could consider the different sectors.

ii. The study has considered only city of Lahore for data collection, so other cities can be considered in future for collecting data.

iii. Another limitation is the study design. Current investigation is cross-sectional and collected data at one point in time. Longitudinal studies could be done as to determine the relationships between variables.

\section{RECOMMENDATIONS}

There are some recommendations that are offered as possible ways to improve this study. Following are those recommendations:

i. Leadership is necessary for every organization and executives should be cognizant of the ways to get positive results from employees in order to improve the productivity of organization.

ii. Managers should consider the ways of keeping employees committed and satisfied at workplace.

iii. Managers should encourage the employees and allow them to take part in decision-making.

\section{REFERENCES}

Aksu, A. (2009). Total quality management and visionary leadership in primary schools. Education and Science, 34(153), 99-116.

Albion, M. J. \& Gagliardi, R. E. (2007). A study of transformational leadership, organizational change and job satisfaction", In: 7th Industrial \& Organizational Psychology Conference and 1st Asia Pacific Congress on Work and Organizational Psychology, 28 June - 1 July 2007, Adelaide, Australia.

Al-Shurafat, M., \& Halim, B.B.A. (2018). A Review of Organisational Culture and Organizational Commitment. IOSR Journal of Business and Management (IOSR-JBM), 20 (3), 21-26.

Alvesson, M., \& Kärreman, D. (2016). Intellectual failure and ideological success in organization studies: The case of transformational leadership. Journal of Management Inquiry, 25(2), 139-152.

Anitha, J., \& Begum, F. N. (2016). Role of organisational culture and employee commitment in employee retention. ASBM Journal of Management, 9(1), 17.

Avolio, B. J., Gardner, W. L., Walumbwa, F. O., Luthans, F. \& May, D. R. (2004). Unlocking the mask: A look at the process by which authentic leaders impact follower attitudes and behaviors. The Leadership Quarterly, 15(6), 801-823.

Aycan, Z. (2006). Paternalism: Towards conceptual refinement and operationalization. In K. S. Yang, K. K. Hwang, \& U. Kim (Eds.), Indigenous and cultural psychology: Understanding people in context (pp. 445466). New York, NY: Springer.

Azizollah, A., Abolghasem, F. \& Amin, D. M. (2016), The Relationship Between Organizational Culture and Organizational Commitment in Zahedan University of Medical Sciences. Glob Journal of Health Science, 8(7): 195-202.

Bass, B. M. (2008). The Bass handbook of leadership: Theory, research, and managerial applications (4thed.). New York: Free Press.

Bedi, A. (2019). A Meta-Analytic Review of Paternalistic Leadership, International Association of Applied Psychology, doi: 10.1111/apps.12186.

Brewster, C. (2017). The integration of human resource management and corporate strategy. In Policy and practice in European human resource management (pp. 22-35). Routledge.

Bushra, F., Usman, A. \& Naveed, A. (2011). Effect of transformational leadership on employees' job satisfaction and organizational commitment in banking sector of Lahore (Pakistan). International Journal of Business and Social Science, 2(18), 261- 267.

Cameron, K.S. \& Freeman, S.J. (1991). Cultural congruence, strength, and type: relationships to effectiveness. Research in Organizational Change and Development, 5(1), 23-58.

Cameron, K.S. \& Quinn, R.E. (1999). Diagnosing and changing organizational culture. Reading, MA: Addison Wesley Longman.

Carvalho, C. R. S. P., Castro, M. A. R., Silva, L. P., \& Carvalho, L.O.P. (2018). The Relationship Between Organizational Culture, Organizational Commitment and Job Satisfaction. REBRAE, 11(2), 201-215.

Celik, S., Dedeoglu, B. B., \& Inanir, A. (2015). Relationship Between Ethical Leadership, Organizational Commitment and Job Satisfaction at Hotel Organizations. Ege Academic Review, 15(1), 53-63.

Chan, S. C., Huang, X., Snape, E. \& Lam, C. K. (2012). The Janus face of paternalistic leaders: Authoritarianism, benevolence, subordinates' organization-based self-esteem, and performance. Journal of Organizational Behavior, 34(1), 108-128.

Chang, R. (2000). Dollarization - A scorecard. Economic Review of the Federal Reserve Bank of Atlanta, 3. 
Chen, X. P., Eberly, M. B., Chiang, T. J., Farh, J. L., \& Cheng, B. S. (2014). Affective trust in Chinese leaders linking paternalistic leadership to employee performance. Journal of Management, 40(3), 796-819.

Ciralkar, N.H., Ucar, Z. \& Sezgin, O.B. (2016). Effects of Paternalistic Leadership on Organizational Identification: Mediating Role of Trust in Leader, Research Journal of Business and Management, 3(1), 73-87.

Daft, R.L. (2005). The Leadership Experience. $3^{\text {rd }}$ Edition, Thomson-Southwestern, Vancouver.

Den Hartog, D. N. (2004). Assertiveness. In House, R. J., Hanges, P. J., Javidan, M., Dorfman, P. W. and Gupta, V. (Eds.), Culture, leadership, and organizations: The GLOBES study of 62 societies (pp. 395-436). Thousand Oaks, CA: Sage Publications.

Detert, J., Schroeder, R.G., \& Mauriel, J. (2000). A framework for linking culture and improvement initiatives in organizations. Academy of Management Review, 25(4), 850-863.

Dickson, M. W., Den Hartog, D. N. \& Mitchelson, J. K. (2003). Research on leadership in a cross cultural context: Making progress, and raising new questions. Leadership Quarterly, 14(6), 729-769.

Dorfman, P.W. (1996). International and cross-cultural leadership research: In B.J. Punnett \& O. Shenkar (Eds.), Handbook for international management research (pp. 267-349). Oxford, UK: Blackwell.

Edward, M. T. (2016). An Organizational Learning Framework for Patient Safety. American Journal of Medical Quality, $1-8$.

Elele, J. \& Fields, D. (2010). Participative decision making and organizational commitment Comparing Nigerian and American employees. Cross Cultural Management: An International Journal, 17(4), 368-392.

Erben, G. S. \& Guneser, A. B. (2008). The Relationship between Paternalistic Leadership and Organizational Commitment: Investigating the Role of Climate Regarding Ethics. Journal of Business Ethics, 82(4), 955968.

Erkutlu, H. (2008). The impact of transformational leadership on organizational and leadership effectiveness: the Turkish case. Journal of Management Development, 27(7), 708-726.

Farh, J. L., Liang, J., Chou, L. F. \& Cheng, B. S. (2008). Paternalistic leadership in Chinese organizations: Research progress and future research directions. In C. C. Chen and Y. T. Lee (Eds.), Leadership and management in China: Philosophies, theories, and practices (pp. 171-205), London: Cambridge University Press.

Firth, L., Mellor, D. J., Moore, K. A. \& Loquet, C. (2004). How Can Managers Reduce Employee Intention to Quit?. Journal of Managerial Psychology, 19(2), 170-187.

Fisher, R., Boyle, M. V. \& Fulop, L. (2010). How gendered is organizational commitment? The case of academic faculty. International Journal of Organizational Analysis, 18(3), 280-294.

Fischer, R. \& Mansell, A. (2009). Commitment across cultures: A meta-analytical approach. Journal of International Business Studies, 40(1), 1339-1358.

Gelfand, M. J., Erez, M. \& Aycan, Z. (2007). Cross-cultural organizational behavior. Annual Review of Psychology, $58(1), 479-514$.

Goffee, R. \& Jones, G. (1998). The Character of a Corporation: How Your Company's Culture Can Make or Break Your Business, Harper Business, London.

Gupta, N., \& Sharma, V. (2016). Exploring employee engagement-a way to better business performance. Global Business Review, 17, 45S-63S.

Hadian, D. (2017), The Relationship Organizational Culture and Organizational Commitment on Public Service Quality; Perspective Local Government in Bandung, Indonesia. International Review of Management and Marketing, 7(1), 230-237.

Harwiki, W. (2016). The impact of servant leadership on organization culture, organizational commitment, organizational citizenship behaviour (OCB) and employee performance in women cooperatives. Procedia Social and Behavioral Sciences, 219, 283-290.

Hofstede, G. (2001). Consequences: Comparing Values, Behaviors, Institutions, and Organizations across Nations, Sage, Thousand Oaks, CA.

Inanlou, Z., \& Ahn, J. Y. (2017). The Effect of Organizational Culture On Employee Commitment: A Mediating Role Of Human Resource Development In Korean Firms. Journal of Applied Business Research (JABR), 33(1), 87-94.

Ismail, A., \& Razak, M. R. A. (2016). Effect Of Job Satisfaction On Organizational Commitment. Management and Marketing Journal, 14(1), 25-40.

Kanungo, S., Sadavarti, S. \& Srinivas, Y. (2001). Relating IT strategy and organizational culture: an empirical study of public sector units in India. Journal of Strategic Information Systems, 10(1), 29-57.

Kaplan, M., \& Kaplan, A. (2018). The Relationship between Organizational Commitment and Work Performance: a Case of Industrial Enterprises. Journal of Economic and Social Development (JESD), 5(1), 46-50.

Lecturer, I. (2018). Analysis of organizational culture, competence and work motivation: The effect on satisfaction and performance of government employees of parepare. Russian Journal of Agricultural and Socio-Economic Sciences, 74(2), 148-155. 
Li, Y.C. (2004). Examining the effect of organization culture and leadership behaviours on organizational commitment, job satisfaction, and job performance at small and middle-sized firms of Taiwan. Journal of American Academy of Business, 5(1/2), 432-8.

Liu, Y. (2014). Exploring the impact of organizational culture on paternalistic leadership in Chinese SMEs, World Journal of Management, 5 (1), 1-19.

Lok, P. \& Crawford, J. (2001). Antecedents of organizational commitment and the mediating role of job satisfaction. Journal of Managerial Psychology, 16(7/8), 594-613.

Malhotra, N. \& Mukherjee, A. (2004). The relative influence of organisational commitment and job satisfaction on service quality of customer contact employees in banking call centers. Journal of Services Marketing, 18(3), 162-174.

Marks, M.A., Mathieu, J.E. \& Zaccaro, S.J. (2001). A temporally based framework and taxonomy of team processes. Academy of Management Review, 26(3), 356-76.

McNeese-Smith, D.K. (1997). The influence of manager behavior on nurses' job satisfaction, productivity and commitment. Journal of Nursing Administration. 27(9), 47-55.

Meyer, J. P. \& Allen, N. J. (1990). The measurement and antecedents of effective continuance and normative commitment to the organization. Journal of Occupational Psychology, 63(1), 1-18.

Mitic, S., Vukonjanski, J., Terek, E., Gligorovic, B., \& Zoric, K. (2016). Organizational Culture and Organizational Commitment: Serbian Case. Journal of Engineering Management and Competitiveness, 6 (1), 21-27.

Mohammadi, Z., \& Zarei, R. (2015). The Relationship between Organizational Culture and Organizational Commitment by Benefiting by Fajr Jam Refinery. European Online Journal of Natural and Social Sciences, 4 (1), 1672-1680.

Northouse, P. G. (2007). Leadership: Theory and Practice. Thousand Oaks: Sage Publications, Inc.

Obeidat, D., Yousef, B., Tawalbeh, H. F., \& Masa'deh, R. E. (2018). The Relationship between Human Resource Management (HRM) Practices, Total Quality Management (TQM) Practices and Competitive Advantages. Modern Applied Science, 12(11), 17-34.

Oner, Z. H. (2012). Servant leadership and paternalistic leadership style in the Turkish business context: A comparative empirical study. Leadership \& Organization Development Journal, 33(3), 300-316.

Paquin, H., Bank, I., Young, M., Nguyen, L. H., Fisher, R., \& Nugus, P. (2018). Leadership in crisis situations: merging the interdisciplinary silos. Leadership in Health Services, 31(1), 110-128.

Pearce J. L. (2005). Paternalism and Radical Organizational Change. Paper Presented at the Meeting of the Academy of Management, Honolulu, Hawaii.

Pellegrini, E. K. \& Scandura, T. A. (2008). Paternalistic leadership: a review and agenda for future research. Journal of Management, 34(3), 566-93.

Poskiene, A. (2006). Organizational Culture and Innovations. Engineering Economics, 46(1), 45-50.

Quinn, R.E. \& Rohrbaugh, J. (1983). A spatial model of effectiveness criteria: towards a competing values approach to organizational analysis. Management Science, 29(3), 363-77.

Randeree, K. \& Chaudhry, A.G. (2012). Leadership-style, satisfaction and commitment: An exploration in the United Arab Emirates' construction sector. Engineering, Construction and Architectural Management, 19(1), 61-85.

Rashid, M.Z.A., Sambasivan, M. \& Johari, J. (2003). The influence of corporate culture and organizational commitment on performance. Journal of Management Development, 22(8), 708-28.

Rehman, M. \& Afsar, B. (2012). The impact of Paternalistic Leadership on Organization Commitment and Organization Citizenship Behaviour. Journal of Business Management and Applied Economics, 1(5), 148159.

Reichers, A. E. (1985). A Review and Reconceptualization of Organizational Commitment. Academy of Management Review, 10(3), 465-476.

Rukmani, K., Ramesh, M. \& Jayakrishnan, J. (2010). Effect of leadership styles on organizational effectiveness. European Journal of Social Sciences, 15(3), 365-370.

Samuel O. J. (2011). Leadership Behaviour, Organisational Commitment, Job Satisfaction and Service Quality in Commercial Banks in Uganda- A Case of Kampala District. Master Thesis, Makerere University.

Schein, E.H. (2004). Organizational Culture and Leadership. San Francisco: Jossey Bass.

Silverthorne, C. (2004). The impact of organizational culture and person-organization fit on organizational commitment and job satisfaction in Taiwan. Leadership \& Organization Development Journal, 25(7), 592599.

Sinaga, H.J., Asmawi, M. Madhakomala, R. \& Adji, S. (2018). Effect of Change in Management, Organizational Culture and Transformational Leadership on Employee Performance PT. AdhyaTirta Batam (PT. ATB). International Review of Management and Marketing, 8(6), 15-23.

Srithongrung, A. (2011). The causal relationships among transformational leadership, organizational commitment, 
and employee effectiveness. International Journal of Public Administration, 34(6), 376-388.

Stites, J. \& Michael, J. (2011). Organizational commitment in manufacturing employees: relationships with corporate social performance. Business \& Society, 50(1), 50-70.

Stone, D. L., Deadrick, D. L., Lukaszewski, K. M., \& Johnson, R. (2015). The influence of technology on the future of human resource management. Human Resource Management Review, 25(2), 216-231.

Sutton, C. N. \& Jenkins, B. (2007). The Role of the Financial Services Sector in Expanding Economic Opportunity. Corporate Social Responsibility Initiative Report No. 19, Cambridge, MA; Kennedy School of Government, Harvard University.

Uhl-Bien M. \& Maslyn M. (2005). Paternalism as a Form of Leadership: Differentiating Paternalism from Leader Member Exchange. Paper Presented at the Meeting of the Academy of Management, Honolulu, Hawaii.

Van Vugt, M. (2006). Evolutionary origins of leadership and followership. Personality and Social Psychology Review, 10(4), 354 -371.

Wallach, E.J. (1983). Individuals and organizations: the cultural match. Training and Development Journal, 37(2), 28-36.

Walumbwa, F. O. \& Lawler, J. J. (2003). Building effective organizations: transformational leadership, collectivist orientation, work-related attitudes, and withdrawal behaviors in three emerging economies. International Journal of Human Resource Management, 14(7), 1083-1101.

Wambui, L.N. \& Gichanga L. (2018). Impact of Organizational Culture on Organizational Commitment. Strategic Journal of Business \& Change Management, 5(2), 2076 - 2088.

Watson, T.J. (2006). Organizing and Managing Work, UK: Pearson Education Limited.

Wieselsberger, K. (2004). The Psychological Contract is Dead, Long Live the Psychological Contract: Issues of Talent Management and Retention in the Context of the New Employment Relationship. London School of Economics, August.

Williams, L.J. \& Hazer, J.T. (1986). Antecedents and consequences of satisfaction and commitment in turnover models: a re-analysis using latent variable structural equation methods. Journal of Applied Psychology, 71(2), 219-31.

Williams, M.R. \& Attaway, J.S. (1996). Exploring salespersons' customer orientation as a mediator of organizational culture's influence on buyer-seller relationships. The Journal of Personal Selling \& Sales Management, 16(4), 33-52.

Wiseman, N., Ngirande, H., \& Setati, S.T. (2017). Existing organizational culture typologies and organizational commitment at a selected higher education institution in South Africa. Investment Management and Financial Innovations, 14(2-1), 242-251.

Yamane, T. (1967). Statistics: An Introductory Analysis. $2^{\text {nd }}$ edition. New York: Harper and Row.

Yiing, L. H. \& Ahmad, K. Z. (2009). The moderating effects of organizational culture on the relationships between leadership behavior and organizational commitment and between organizational commitment and job satisfaction and performance. Leadership \& Organization Development Journal, 30(1), 53-86.

Yousef, D. A. (2017). Organizational commitment, job satisfaction and attitudes toward organizational change: A study in the local government. International Journal of Public Administration, 40(1), 77-88.

Yukl, G. (2002). Leadership in organizations, $5^{\text {th }}$ edition. Upper Saddle River, NJ: Prentice Hall.

Yuzbasioglu, N. \& Dogan, O. (2018), Relationship between Paternalistic Leadership and Organizational Commitment in Hospitality Industry: Case of Antalya, Turkey. Academic Journal of Interdisciplinary Studies, $7(1), 163-173$.

Zhang, Y., Huai, M. and Xie, Y. (2015), Paternalistic leadership and employee voice in China: a dual process model. The Leadership Quarterly, 26(1), 25-36. 